\title{
Study of Venturia inaequalis pseudothecia development and apple scab severity under Polish conditions
}

\author{
Beata Meszka \\ Research Institute of Horticulture \\ Pomologiczna 18, 96-100 Skierniewice, Poland
}

\begin{abstract}
Studies conducted during 2009-2013 at the Experimental Orchard located in the central region of Poland showed that the highest number of $V$. inaequalis pseudothecia occurred on 'McIntosh' and 'Cortland' leaves. A smaller number of pseudothecia was found on the leaves of the Alwa and Jonagold cultivars, but there were no statistical differences. The first discharges of ascospores were noted at a similar time on the leaves of all of the apple cultivars, usually at the end of March or in early April. For the forecasting of ascospore discharges and dates of critical periods, a simulation model by RIMpro was used. The number of critical periods and apple scab severity differed in each season. The most critical periods (above 20) were recorded in 2010 and 2013, which also corresponded with a high severity of apple scab. The number of infected leaves and fruits on the untreated trees of the very susceptible cultivar McIntosh reached nearly $100 \%$ during these seasons. In other years, the severity of the disease on the same apple trees was lower and amounted to $30-54 \%$ of infected leaves and $23-80 \%$ of infected fruits.
\end{abstract}

Key words: ascospore, forecasting system, fungal disease, maturation, source of infection

\section{INTRODUCTION}

Apple scab is the most serious fungal disease affecting apple trees. Its causal agent attacks foliage, blossoms and fruits, resulting in the defoliation of trees and making the fruits unmarketable. If the disease is not controlled, over $80 \%$ of fruits of susceptible cultivars can be damaged. Depending on the risk of disease, 10 to 15 or even more fungicidal applications are usually needed for efficient control. The number of treatments depends on cultivar susceptibility, the amount of source infection and weather conditions, mainly air temperature, leaf wetness, relative humidity and rainfall (Gadoury et al. 1998, Stensvand et al. 1998, Carisse et al. 2007). Information about the development of $V$. inaequalis pseudothecia and ascospore discharge is required to determine the proper time to start the chemical control against apple scab. Its causal agent generally overwinters on fallen leaves lying on the orchard floor (MacHardy 1996). In Poland, the ascospores normally mature on dead leaves at the same time as the tree buds break (Meszka et al. 2002, Meszka and Bielenin 2006). Fully controlling apple scab disease requires extensive knowledge, both in terms of combating time, as well as the types of fungicides effective against the disease. Numerous simulation models are currently available for assessing primary $V$. inaequalis infection risks (Trapman and Polfliet 1997, Rossi et al. 2007). There are computer programs (software) such as AppleScab (Blaise et al. 1987), VentemTM (Butt et al. 1992), RIMpro (Trapman 1994) and 
Welte (Aalbers et al. 1998), whose main purpose is to optimize the use of fungicides in the proper time. Computer models estimate the severity of apple scab infection, depending on the cultivar resistance, weather changes and information received for the pathogen. The Relative Infection Measure programme (RIMpro) created by Marc Trapman (www.biofruitadvies.nl) is the most commonly used in Poland for the biology of the main pests and diseases in apple fruit.

The aim of this work was to assess the development and maturation of $V$. inaequalis pseudothecia on different apple cultivars, determining the number of critical periods and apple scab severity on untreated apple trees cv. McIntosh.

\section{MATERIAL AND METHODS}

The experiments were conducted during 20092013 at the Experimental Orchard in Dąbrowice. Scabbed leaves of four apple cultivars - Alwa, Cortland, Jonagold and McIntosh - were collected in the autumn and stored in nylon mesh bags on the orchard ground. The following spring, from the beginning of March, samples of 100 pseudothecia in each of four replications from 10 leaves of each cultivar were assessed every 7-10 days (10 terms of leaf collection) and microscopic observations for the presence of ascospores and their development were performed. The number of pseudothecia per $1 \mathrm{~cm}^{2}$ of the four scab lesions on each leaf was counted. Then, 10 pseudothecia from each leaf were taken, crushed on microscopic slides and checked for maturity using a 5-degree scale (1 - pseudothecia without asci, 2 - pseudothecia with asci but no spores, 3 - less than $10 \%$ asci with ascospores, 4 - from 10 to $30 \%$ of asci with ascospores, 5 - over $30 \%$ of asci with matured ascospores) (Borecki and Cichosz 1961, Meszka and Bielenin 2002). Szkolnik (1969) defined five similar stages in ascus development, the observations being based on crushed perithecia: (i) asci formed but contents undifferentiated, (ii) asci containing spores in the process of formation, (iii) spores are all formed, usually septate but uncoloured, (iv) asci containing spores that are formed, septate and olivaceous in colour, indicating that the spores are mature, (v) empty asci.

Apple scab severity was evaluated by the analysis of infected leaves and fruit on untreated McIntosh trees. Observations were made on 200 leaves from each of the four replications (sample of 800 leaves) and on 100 fruits in each of four replications (sample of 400 fruits). The level of leaf infection was assessed using the 6-degree scale $(0$ - no symptoms, 5 - more than $75 \%$ of leaf surface covered by scab lesions according to the EPPO standard PP 1/5 (3)). For fruit infestation, the 3 -degree scale ( 1 - no symptoms, $2-1-3$ spots on the fruit, 3 - more than 3 spots on the fruit) according to the EPPO standard PP 1/5 (3) was used.

The number of critical periods was assessed using the meteorological station METOS and the RIMpro programme. The term of the 'critical period' is the time in which the leaves, buds or fruits are infected by germinating spores of the fungus. To its designation temperature measurements were necessary when leaves, buds and fruits were wet, as well as the relative humidity in the intervals between consecutive periods of apple organ wetting. To facilitate these studies a METOS meteorological station was established in the experimental orchard. Hourly records of temperature, rainfall, wind velocity, relative humidity and periods of bright sunshine were obtained from this station. Average temperature and rainfall are given in Figure 1 in each of the seasons. These data are correlated with a series of records that have been developed for tracing certain significant aspects of the seasonal development of the fungus, the apple plant, the disease and the effectiveness of control measures. RIMpro provides hour-by-hour data on the situation and is considered by most users to be a reliable model. Forecasting is usually done by extrapolating the temperature and humidity data for the previous 24 hours, and by extending the wetting.

The results were evaluated statistically by analysis of variance and the differences between means were estimated by Newman-Keul's test at a $p=0.05$ level of significance. Percentages were initially transformed by the Bliss function.

\section{RESULTS AND DISCUSSION}

The results showed that the development of pseudothecia was correlated with the apple cultivar. During the years of observations, the highest number of pseudothecia, ranging from 32 to 59 per $\mathrm{cm}^{2}$ of lesion, was noted on 'McIntosh' leaves. A similar number was observed on 'Cortland' leaves with the exception of 2009, while their number was lower (18-30 per $\left.\mathrm{cm}^{2}\right)$ on 'Alwa' and 'Jonagold' leaves, except for 2009 and 2010, and there were no significant differences noted for 'Jonagold' (Tab. 1). Similar results were obtained during earlier experiments conducted by Meszka and Bielenin (2002) in 1998-2001. During the 2010 

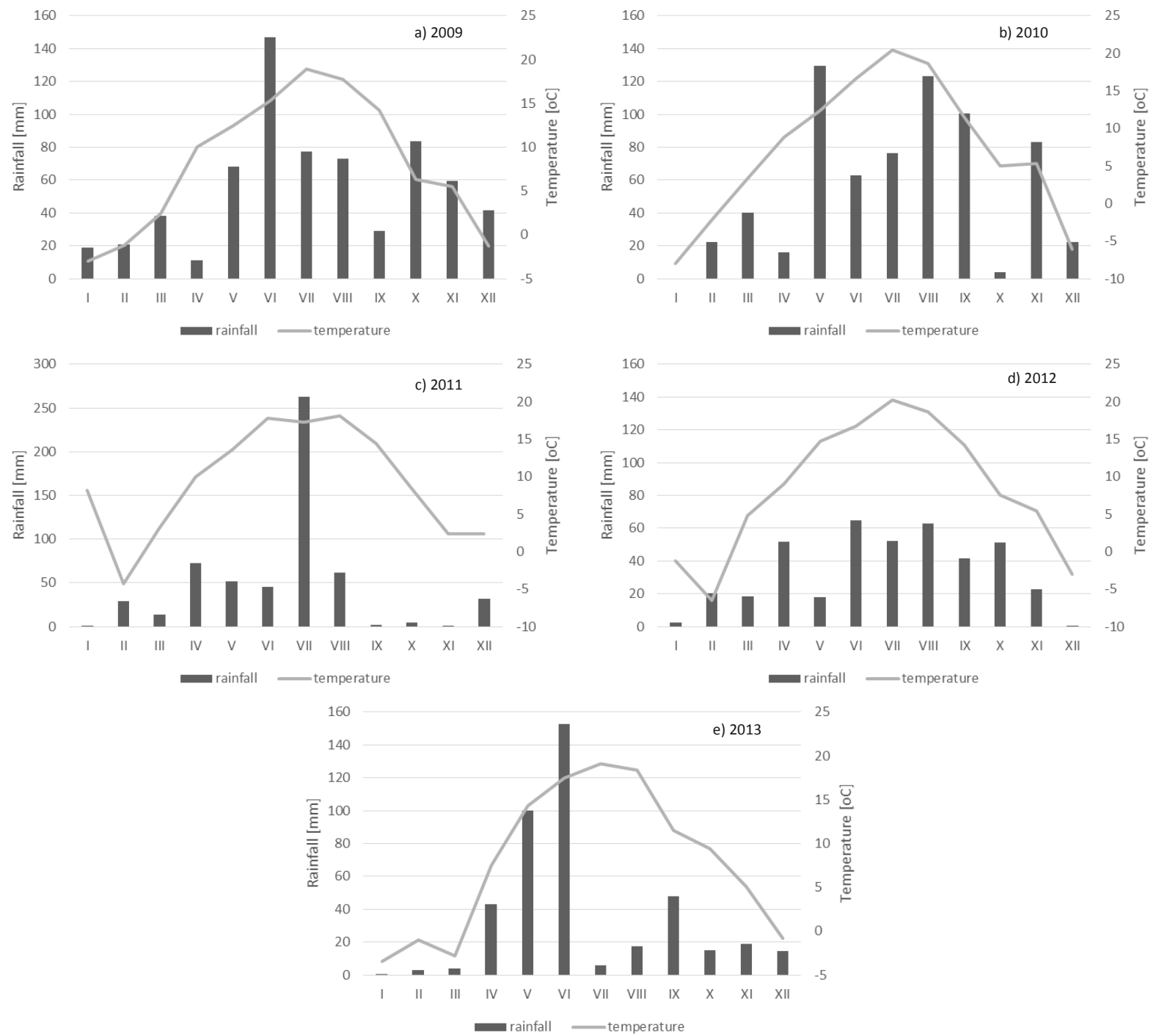

Figure 1. Weather conditions (temperature and rainfall) during the 2009-2013 seasons

and 2013 seasons, the total number of $V$. inaequalis pseudothecia on McIntosh and Cortland cultivars was higher by about $20-50 \%$, respectively, as compared to other seasons (Tab. 1). This could be correlated with favourable weather conditions for the development of the sexual stage of $V$. inaequalis during the autumn of 2009 and 2012. The average temperature during October and November, when the first perithecia were formed, was between $5-7^{\circ} \mathrm{C}$ (Figs 1a and 1d). At leaf-fall, wetness and temperature are important in determining both the numbers of pseudothecia initiated and their early development, but there's no general agreement on the cardinal temperatures for initiation. In early spring, wetness and temperature affect the maturation of ascospores in the ascus (Jeger et al.

Table 1. The effect of apple cultivar on pseudothecial density

\begin{tabular}{lccccc}
\hline \multirow{2}{*}{ Cultivar } & \multicolumn{5}{c}{ The average number of pseudothecia per $1 \mathrm{~cm}^{2}$ of scab lesion } \\
\cline { 2 - 6 } & 2009 & 2010 & 2011 & 2012 & 2013 \\
\hline McIntosh & $32.1 \mathrm{~b}^{*}$ & $58.8 \mathrm{~b}$ & $38.9 \mathrm{a}$ & $38.9 \mathrm{a}$ & $41.2 \mathrm{a}$ \\
Cortland & $18.0 \mathrm{a}$ & $44.3 \mathrm{~b}$ & $36.5 \mathrm{a}$ & $29.0 \mathrm{a}$ & $43.6 \mathrm{a}$ \\
Alwa & $28.9 \mathrm{~b}$ & $\mathrm{X}$ & $31.2 \mathrm{a}$ & $21.0 \mathrm{a}$ & $\mathrm{X}$ \\
Jonagold & $22.0 \mathrm{a}$ & $18.6 \mathrm{a}$ & $27.3 \mathrm{a}$ & $\mathrm{X}$ & $32.0 \mathrm{a}$ \\
\hline
\end{tabular}

*Values marked with the same letters do not differ significantly at $\mathrm{p}=0.05$

$\mathrm{X}$ - Not tested 
1982). According to James and Sutton (1982), no perithecia appeared on leaves placed in dry air. If moisture is not a limiting factor, temperature has a major influence on perithecia development phases. Perithecia formation starts as soon as the temperature exceeds $4^{\circ} \mathrm{C}$. The most pseudothecia formation is noted between 6 to $20^{\circ} \mathrm{C}$ (Gadoury and MacHardy 1982). A continuous supply of moisture is required for pseudothecial formation and the maturation of $V$. inaequalis in naturally infected apple leaves (James and Sutton 1982). In this study the most favourable temperature, about $5^{\circ} \mathrm{C}$ during early spring (March), was noted in 2009 and 2012 (Figs la and 1d). Many plant pathogenic ascomycetes like $V$. inaequalis, the cause of apple scab, Ascochyta rabei, the cause of Ascochyta blight of chickpea, and Pyrenopeziza brassicae, the cause of light leaf spot of canola, have much lower optimum temperatures for the formation and development of pseudothecia (Ross and Hamlin 1962, Müller 1979, Trapeo-Casas and Kaiser 1992, Gilles et al. 2001). These are all pathogens of temperate crops and their sexual stages often develop very early in spring under low temperatures. However, in the case of 'Jonagold', the number of pseudothecia was not affected by these factors and remained steady in all seasons. This cultivar is less susceptible to infection by $V$. inaequalis than 'McIntosh', and therefore the number of forming pseudothecia may be lower. The environmental conditions required for pseudothecial formation help to explain the time of peak ascospore release under different management practices.

Smith and MacHardy (1992) observed the highest number of pseudothecia on 'Red Delicious', 'Rome' and 'Spartan' leaves, but lower numbers on 'Golden Delicious', 'McIntosh' and 'Stayman'. The authors noted the first matured ascospores on cultivars with a lower number of pseudothecia. Moller (1980) also observed differences in the development of ascospores depending on apple cultivars. A study in California found that the maximum discharges from the leaves of six apple cultivars occurred in the same week, but depending on the apple cultivar the number of discharged ascospores was considerably different. Similarly, Smith and MacHardy (1992) observed significant differences in the maturation of $V$. inaequalis perithecia depending on the cultivars. They showed that on the Stayman cultivar the maturation of pseudothecia was earlier, although their number on the leaves of this cultivar was the smallest. Among researchers, there are two hypotheses to explain the differentiated rate of pseudothecia maturation on the leaves on apple cultivars. According to some, it is correlated with the aggressiveness of the pathogen during the parasitic phase, which has an influence on the dynamics of pseudothecia formation and ascospore maturation during the saprotrophic phase. Palmiter (1932) and Wiesmann (1932) are proponents of this concept, which is based on in vitro studies. The other concept, which is based on Jeger et al. (1982), assumes that the rate of pseudothecia maturation depends not on the period of the parasitic fungus, but only on the saprotrophic phase. The authors give the Red Delicious cultivar as an example, on the leaves of which pseudothecia of $V$. inaequalis formed first and in large numbers, although in the autumn they were less affected than the leaves of other apple cultivars. A different relationship was noted on Kent cultivar, on which apple scab occurred in very high severity, but the number of pseudothecia produced was small and they reached full maturity more slowly. A close correlation between the severity of scab and the number and rate of pseudothecia maturation was recorded only on the leaves of 'McIntosh'. Data about ascospore maturity is very important when advising farmers on when to start the application of plant protection products for scab management. Under Polish conditions, the most useful cultivars for early warning seem to be 'McIntosh', 'Cortland' and 'Alwa'.

The obtained data showed that the maturation of pseudothecia was similar on the leaves of all of the apple cultivars. The first matured pseudothecia (30\% of asci with ascospores) filled with ready to discharge ascospores were usually observed between late March ( $3^{\text {rd }} 10$-week period) and the first 10-week period of April (Figs 2a-e). It was during the 'bud break' or 'green tip' phenological phases, when suitable temperatures and moisture promote the release of $V$. inaequalis ascospores. The 'bud break' or 'green tip' stages have often been used as a starting point to estimate ascospore release (Stensvand et al. 2005), but in warm temperate (low latitude) regions, like Brazil and northern parts of New Zealand, ascospore release may be well advanced by green tip. The same situation was observed for Venturia pirina development in Australia (Eikemo et al. 2011). The maximum of pseudothecia maturation on the leaves of all of the apple cultivars was reached during late April and the beginning of May (Figs 2 a-e). Therefore, the largest spore discharges and infection periods took place between the 'pink bud' phase and the 

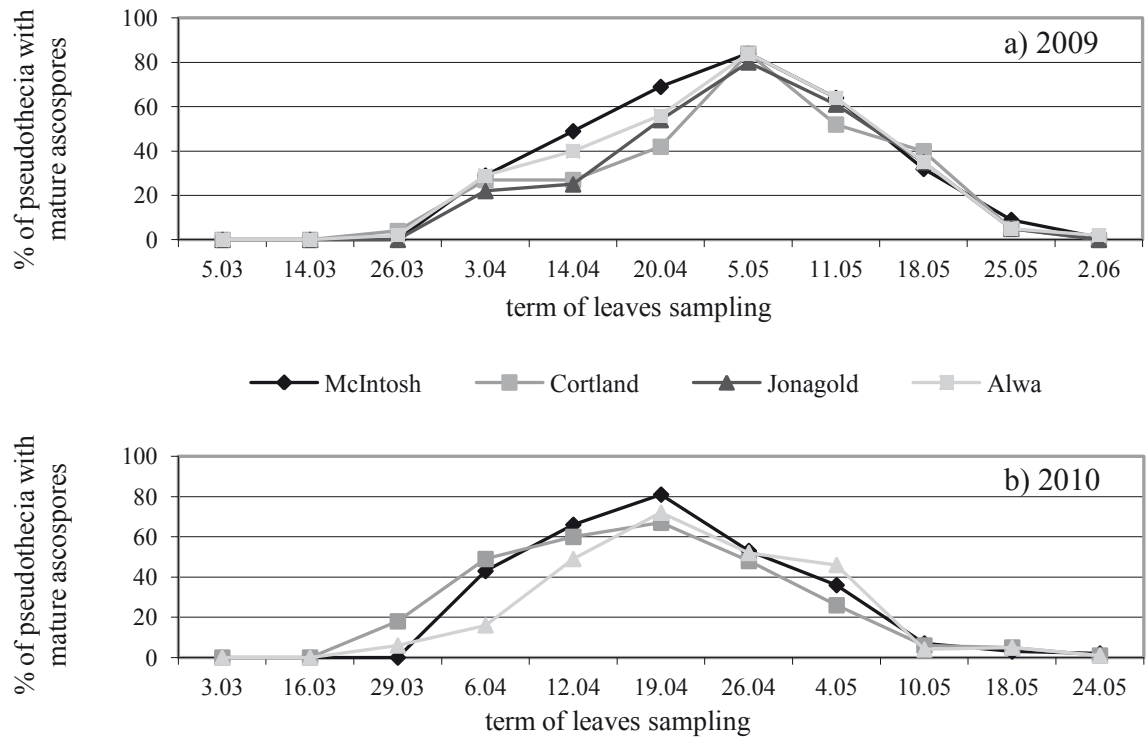

$\longrightarrow$ McIntosh $\quad-$ Cortland Jonagold
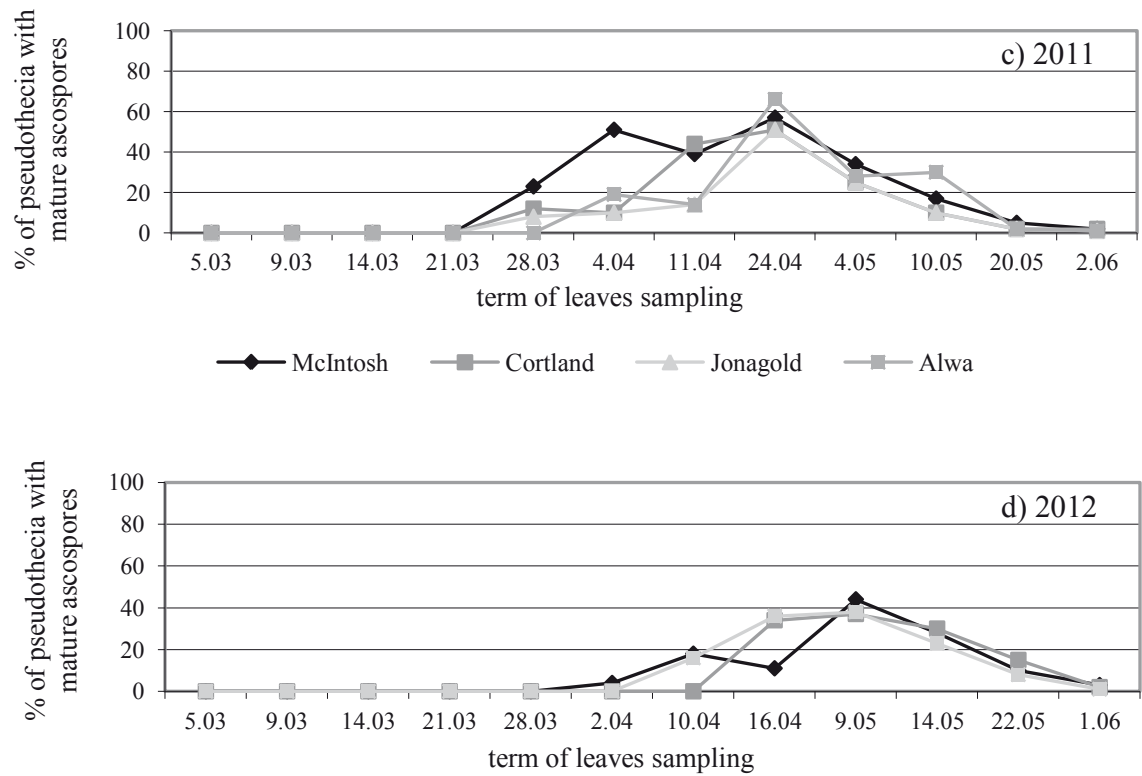

$\longrightarrow$ McIntosh $\longrightarrow$ Cortland

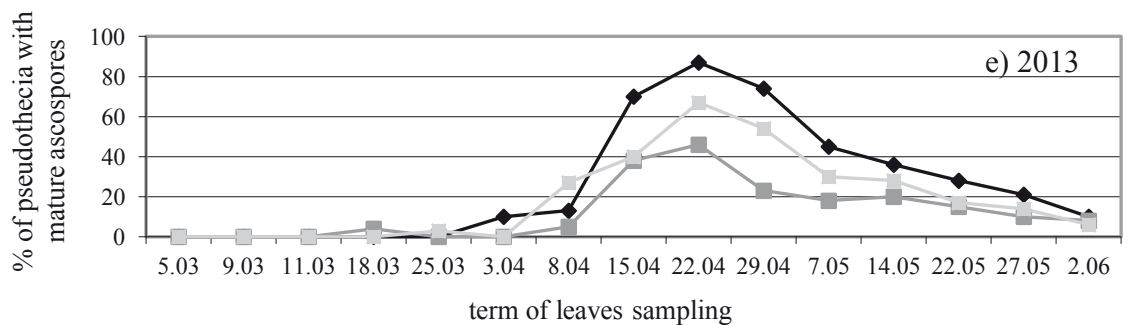

term of leaves sampling

$\longrightarrow$ McIntosh $\longrightarrow$ Cortland

Figure 2. Percentage of matured pseudothecia ( $>30 \%$ asci with ascospores) on the leaves of different apple cultivars

'petal fall phase'. When leaves on the orchard floor become wet from rain, the ascospores are forcibly ejected into the air in daylight. Recently developed models indicate that some $V$. inaequalis ascospores would be transported 2 to $5 \mathrm{~km}$ from the point and area sources of inoculum (Aylor 1998). This discharge continues after rain events until midJune, by which time all of the ascospores have been 


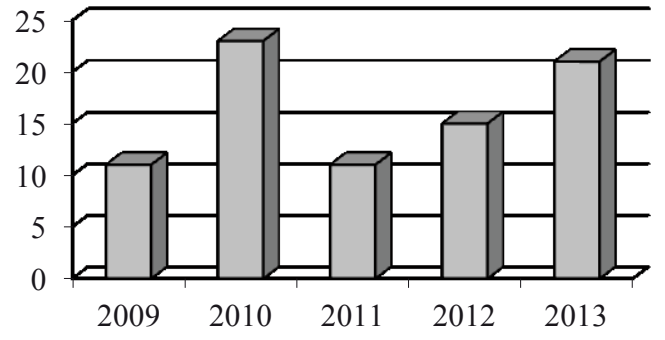

Figure 3. Number of critical periods in the 2009-2013 seasons (Dąbrowice, central Poland)

released. At this time of maximum growth, young plant tissues are highly susceptible to infection. If the leaves and fruitlets remain wet long enough, the ascospores germinate and grow into the tissue. The time needed for germination and infection to take place varies with the temperature and is called the infection period. The number of released ascospores increases substantially and reaches a peak between full flowering and petal fall, as reported MacHardy and Gadoury (1986). After that, the quantity of the released ascospores decreases until the inoculum reserve is exhausted and the perithecia contain no more viable ascospores. The release of mature ascospores from the perithecia is triggered by water. A fine film of water covering the perithecia is necessary for ascospore release (Gadoury and MacHardy 1986). Mature ascospores of $V$. inaequalis remained in about $25 \%$ of the asci in late spring as a result of the weakening of the discharge mechanism. Gadoury and MacHardy (1982) reported that only $2 \%$ of ascospores had not discharged by 1 July. In this study in all of the seasons, the end of the ascospore discharges was noted in the last 10 days of May or in the first days of June (Figs 2 a-e). At this time, usually from 2 to $5 \%$ of the spores still remained in the pseudothecia.
The RIMpro programme provided information about the number of critical periods and possible infection dates. The highest numbers, with more than 20 critical periods, were recorded in the 2010 and 2013 seasons. During 2012 there were 15 periods and about 10 in the remaining years (Fig. 3). Ascospore discharges forecasted by the RIM model were confirmed with microscopic observations of ascospore maturation. Our results demonstrated that PC-based scab warning systems are a valuable tool in the control of apple scab. The determination of the first ascospore discharge and the use of a scab warning system are of great importance for efficient apple scab control (Giosue et al. 2000). PC-based scab warning systems are a considerable help in the control of apple scab. However, attention must be paid to the fact that these systems cannot replace the grower and they can be used successfully in orchards where other technological elements (e.g. irrigation, soil cultivation, pruning) are harmonized.

During the five-year study, the severity of apple scab varied (Fig. 4). The most favourable weather conditions for the development and spread of V. inaequalis occurred in 2010 and 2013. The huge amount of rainfall, about $130 \mathrm{~mm}$ in May 2010 and above $250 \mathrm{~mm}$ during May and June 2013, and a temperature of about $15-20^{\circ} \mathrm{C}$ (Figs $1 \mathrm{~b}$ and 1e) contributed to the occurrence of more than 20 critical periods for apple scab, resulting in very strong infections. In both of these seasons, the percentage of affected leaves and fruits was more than $90 \%$ (Fig. 4) on untreated 'McIntosh' trees (the assessment was made about two weeks after the end of ascospore release). In other years, the severity of the disease on the same apple trees was

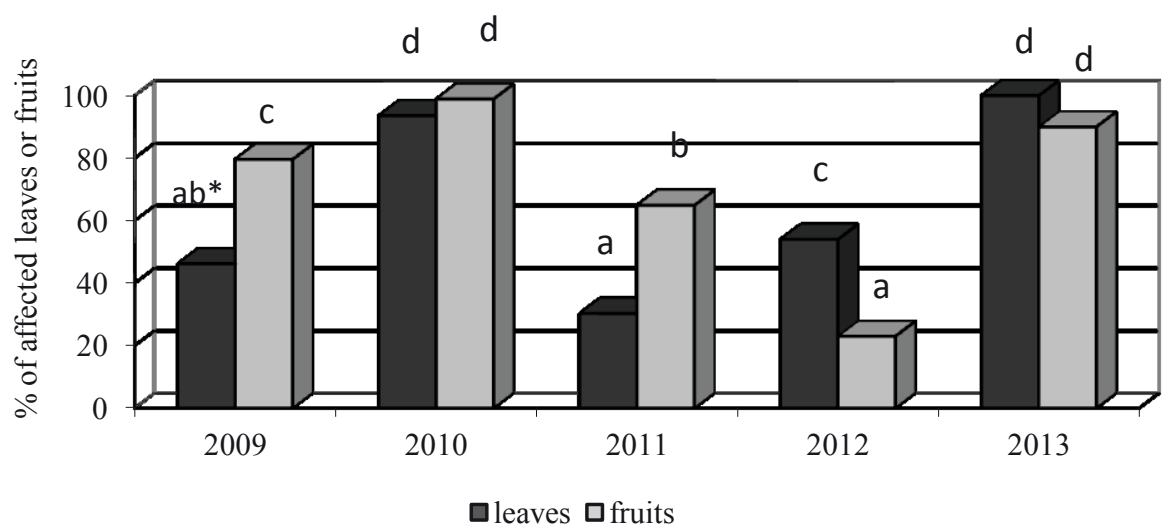

*Values marked with the same letter do not differ statistically at $\mathrm{p}=0.05$. Statistics were done separately for leaves and fruits

Figure 4. Severity of apple scab on untreated McIntosh apple trees 
lower and amounted to $30-54 \%$ of infected leaves and $23-80 \%$ of infected fruits (Fig. 4).

The probable severity of infection has several components: potential ascospore dose, i.e., the size and density of the overwintering pathogen population; target size and susceptibility; detection and rating of favourable environmental periods for infection and spread of disease; and the relative proportion of the pathogen population available for release. The proportion of the season's ascospores available is of greatest consequence when the supply of primary inoculum is exhausted (Gadoury et al. 2004). Annual epidemics of apple scab can be difficult to manage if the primary infection by ascospores is not controlled in the spring; scab spreads to the fruits and extension shoots from lesions established at an early stage on sepals and rosette leaves. Furthermore, the more disease present on extension shoot leaves late in the season, the greater the potential ascospore dose the next spring, because pseudothecia form most abundantly on leaves infected late in the growing season (Xu et al. 1995).

\section{CONCLUSIONS}

1. In Poland, ascospores are the main source of primary inoculum for apple scab infection during spring. The monitoring of ascospore maturation is therefore important because it can help growers to decide when to apply fungicides during the period when ascospores are matured and released.

2. Because of the large number of pseudothecia formed and their early maturation, the leaves of the McIntosh and Cortland cultivars are useful in the management of apple scab.

3. Microscopic examination of matured ascospores in asci can provide an accurate measurement of ascospore maturation and inform the decision to start chemical control against apple scab.

4. Where the spring assessment identifies a high number of pseudothecia (inoculum), growers are warned of the high risk of scab.

5. RIMpro is useful for determining critical periods and the release of ascospores but needs biological observations of pseudothecia development.

6. The greatest severity of apple scab was in seasons with a high amount of precipitation during April and May, which corresponded with pink bud and flowering apple phases that were very susceptible to infection.

\section{REFERENCES}

Aalbers P., Balkhoven M.K., van Burg W.L., 1998. The WELTE scab model. Obstbau 23: 198-202.

Aylor D.E., 1998. The aerobiology of apple scab. Plant Dis. 82: 838-849.

Blaise Ph., Arneson P.A., Gessler C., 1987. APPLESCAB A teaching aid on microcomputers. Plant Dis. 71(7): 574-578.

Borecki Z., Cichosz E., 1961. Observations on ascospores of Venturia inaequalis (Cooke) Aderh. Ischarges in central Poland in 1959. Acta Agrobot. 10(1): 151-175.

Butt D.J., SAnten G.V., Xu X.M., Stone K.B., 1992. Vantem Can apple scab (Venturia inaequalis) infection warning system. Version 3.1. Computer software and manual. HRI East Malling, UK.

Carisse O., Rolland D., Savary S., 2007. Heterogeneity of the aerial concentration and deposition of ascospores of Venturia inaequalis within a tree canopy during the rain. Eur. J. Plant Pathol. 117(1): 13-24.

Eikemo H., Gadoury D.M., Spotts R.A, Villalta O., Creemers P., Seem R.C., et al., 2011. Evaluation of six models to estimate ascospore maturation in Venturia pyrina. Plant Dis. 95: 279-284.

Gadoury D.M., MacHardy W.E., 1982. Effects of temperature on the development of pseudothecia of Venturia inaequalis. Plant Dis. 66(6): 464-468.

Gadoury D.M., MacHardy W.E., 1986. Forecasting ascospore dose of Venturia inaequalis in commercial apple orchards. Phytopathol. 76: 112-118.

Gadoury D.M., Stensvand A., Seem R.C., 1998. Influence of light, relative humidity, and maturity of populations on discharge of ascospores of Venturia inaequalis. Phytopathol. 88(09): 902-909.

Gadoury D.M., Seem R.C., MacHardy W.E., Wilcox W.F., Rosenberger D.A., Stensvand A., 2004. A comparison of methods used to estimate the maturity and release of ascospores of Venturia inaequalis. Plant Dis. 88: 869-874.

Gilles T., Fitt B.D.L., Jeger M.J., 2001. Effects of environmental factors on the development of Pyrenopeziza brassicae (light leaf spot) apothecia on oilseed rape debris. Phytopathol. 91: 392-398.

Giosue S., Rossi V., Ponti J., Bugiani R., 2000. Estimating the dynamics of airborne ascospores of Venturia inaequalis. EPPO Bull. 30: 137-142.

JAmes J.R., Sutton T.B., 1982. Environmental factors influencing pseudothelial development and ascospore maturation of Venturia inaequalis. Phytopathol. 72: 1073-1080.

Jeger M.J., Swait A.A., Butt D.J., 1982. Overwintering of Venturia inaequalis, the causal agent of apple scab, on different cultivars. Ann. Appl. Biol. 100: 91-98.

MacHardy W.E., Gadoury D.M., 1986. Patterns of ascospore discharge by Venturia inaequalis. Phytopathol. 76: 985-990. 
MacHardy W.E., 1996. Apple scab biology, epidemiology and management. St. Paul, MN: Am. Phytopathol. Soc.: 545.

Meszka B., Bielenin A., Masny S., 2002. Development and maturation of pseudothecia of Venturia inaequalis (Cooke) Wint. in leaves of different apple cultivars. Phytopathol. Pol. 25: 5-11.

Meszka B., Bielenin A., 2002. The role of urea in reducing the primary scab infection. Acta Agrobot. 55(1): 225-231.

Meszka B., Bielenin A., 2006. Non-chemical possibilities for control of apple fungal diseases. Phytopathol. Pol. 39: 63-70.

Moller W.J., 1980: Effect of apple cultivar on Venturia inaequalis ascospore emission in California. Plant Dis. 64: 930-931.

MüLlER E., 1979. Factors inducing asexual and sexual sporulation in fungi (mainly Ascomycetes). In: The Whole Fungus. B. Kendric (ed.), National Museum of Natural Sciences, Ottawa: 265-282.

PALmiter D.H., 1932: Variability of Venturia inaequalis in cultural characters and host relations. Phytopathol. 22: 21.

Ross R.G., Hamlin S.A., 1962. Production of perithecia of Venturia inaequalis (Cke.) Wint on sterile apple leaf discs. Can. J. Bot. 40: 525-527.

Rossi V., Giogue S., Bugiani R., 2007. A-scab (Apple scab), a simulation model for estimating risk of Venturia inaequalis primary infetions. IOBC-WPRS Bull. 37: 300-308.

Smith C.A., MacHardy W.E., 1992. The influence of apple cultivar on pseudothecia and ascospore production. Abstr. Phytopathol. 82: 247.
Stensvand A., Amundsen T., Semb L., Gadoury D.M., SEEM R.C., 1998. Discharge and dissemination of ascospores by Venturia inaequalis during dew. Plant Dis. 82(7): 761-764.

Stensvand A., Eikemo H., Gadoury D.M., Seem R.C., 2005. Use of a rainfall frequency threshold to adjust a degree-day model of ascospore maturity of Venturia inaequalis. Plant Dis. 89: 198-202.

SzKolnik M., 1969. Maturation and discharge of ascospores of Venturia inaequalis. Plant Dis. Rep. 53: 534-537.

Trapero-Casas A., Kaiser W.J., 1992. Development of Didymella rabiei, the teleomorph of Ascochyta rabiei, on chickpea straw. Phytopathol. 82: 12611266.

Trapman M.C., 1994. Development and evaluation of a simulation model for ascosporeinfections of Venturia inaequalis. Norweg. J. Agric. Sci., Suppl. 17: 55-67.

Trapman M., Polfliet M., 1997. Management of primary infections of apple scab with the simulation program RIMpro: review of four years field trials. IOBC-WPRS Bull. 20: 241-250.

WiesmanN R., 1932. Untersuchungen uber die Ueberwinterung des Apfelschorfpilzes Fusicladium dendriticum (Wallr.) Fck. im totem Blatt sowie die Ausbreitung der Sommersporen (Konidien) des Apfelschorfpilzes. Landw. Schweiz.: 620-679.

Xu X.M., Butt D.J., Van Santen G., 1995. A dynamic model simulating infection of apple leaves by Venturia inaequalis. Plant Pathol. 44: 865-876.

Received June 13, 2015; accepted July 28, 2015 